\title{
Impact of rainfall deficiency on water resources in the plain Ghriss Wilaya of Mascara (West of Algeria) \\ ${ }^{1}$ Ali Dahmani and ${ }^{2}$ Mohamed, Meddi \\ ${ }^{1}$ University of Mascara Algeria \\ ${ }^{2}$ ENSH Blida Algeria
}

\begin{abstract}
Algeria is one of arid and semi-arid areas, which suffer from long-period drought. Of severe rainfall deficits, adverse consequences on the environment, socio-economic development, water resource quality and quantity, increasing soil degradation. The study area is part of the basin of Wadi El Hammam (western Algeria). A wet period between 1943 and 1975 occurred. A second period of drought occurred during the period 1975 to 2004. The average annual flow is $3.52 \mathrm{~m}^{3} / \mathrm{s}$ (19682004). Thus, four different layers were identified: groundwater, ground limestone lake, the water sands and sandstones and dolomitic limestone aquifer.
\end{abstract}

Keywords: Deficit, water, evapotranspiration, static level.

\section{INTRODUCTION}

The aim of this paper is an approach to the impact of rainfall deficiency on water resources in the plain of Ghris. The study area is located in the watershed of Oued Fekan in the Wilaya of Mascara (west of Algeria). It was found that the years rainfall deficits negatively affect the decrease in surface runoff and lowering of groundwater levels. And consumption by farmers and individual users aggravate the situation.

\section{MATERIAL AND METHODS}

presentation of the study area: The study area is part of the sub-watershed of the river Fekan which covers $1200 \mathrm{~km}^{2}$, which extends between latitudes $35.15^{\circ}$ and $35.50^{\circ}$ north and between longitudes $0^{\circ}$ West and $0.40^{\circ}$ East. It is limited by the BeniChougrane Mountains to the north, the mountains south of Saida (Figure 1).

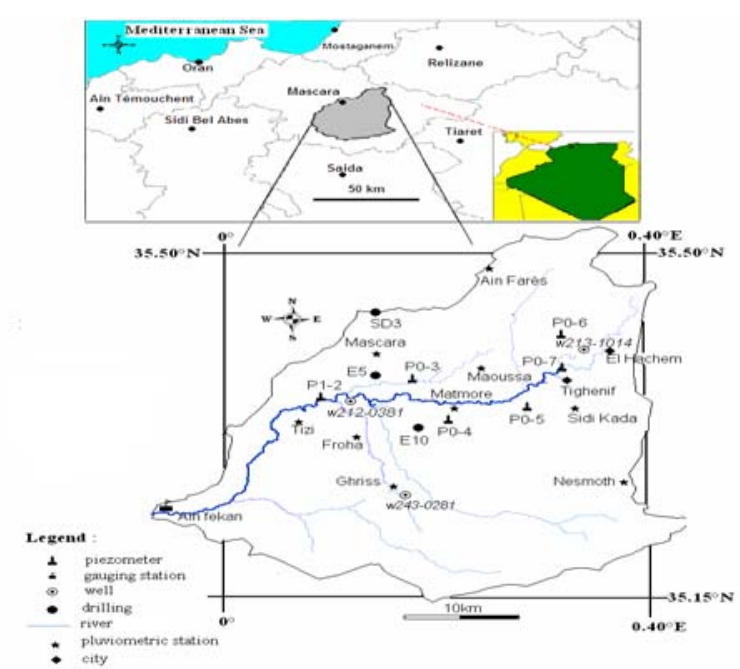

Fig 1: The limits of the sub watershed of Oued Fekan and location of rainfall stations and hydrometric

Acquisition of data: Hydrometric and rainfall data are derived from the National Agency of Water Resources (ANRH). The location of all the rainfall stations and hydrometric is presented in Figure 1 and Table 1. 
Am. J. Sci. Ind. Res., 2011, 2(5): 755-760

Table No. 1: Characteristics of rainfall stations

\begin{tabular}{|c|c|c|c|c|c|c|}
\hline \multirow[b]{2}{*}{$\mathrm{N}^{\circ}$} & \multirow[b]{2}{*}{ Station } & \multirow[b]{2}{*}{ Code } & \multicolumn{3}{|c|}{ Lambert Cordinates } & \multirow{2}{*}{$\begin{array}{c}\text { Period of } \\
\text { service }\end{array}$} \\
\hline & & & $X(\mathrm{~km})$ & $\mathrm{Y}(\mathrm{km})$ & $Z(m)$ & \\
\hline 01 & Matmore & 111405 & 274.0 & 228.5 & 486,60 & 1943-2004 \\
\hline 02 & Ghriss & 111424 & 269.5 & 219.4 & 525,17 & $1942-2004$ \\
\hline 03 & Froha & 111402 & 266.3 & 225.8 & 467,00 & 1943-2004 \\
\hline 04 & Maoussa & 111401 & 277.3 & 233.8 & 494,00 & 1943-2004 \\
\hline 05 & Mascara & 111429 & 268.1 & 235.7 & 577,71 & $1941-2006$ \\
\hline 06 & Sidi Kada & 111414 & 285.9 & 228.3 & 549,00 & 1941-2004 \\
\hline 07 & Tizi & 111413 & 261.5 & 227.8 & 450,28 & 1943-2004 \\
\hline 08 & Ain farès & 111417 & 277.5 & 245.3 & 800,34 & $1943-2004$ \\
\hline 09 & Nesmoth & 111418 & 289,1 & 219,5 & 850.20 & $1940-2002$ \\
\hline 10 & Ain Fekan & 111403 & 253.61 & 216.83 & 314.50 & $1969-2004$ \\
\hline
\end{tabular}

\section{RESULTS AND DISCUSSION}

Variation in rainfall and its deficit: The interannual variation in rainfall and weighted, shows a wet period between 1943 and 1975 except the years 1961, 1962 and 1966 and a drought during the period 1975 to 2004 (Figure 2). The latter is notable for its intensity ever observed throughout the study period to the west (H Azaz, 2001). The year 1981 has the lowest rainfall of $211.7 \mathrm{~mm}$ and less with the year 1964 is the wettest year during the entire study period (573.7mm).

It appears from this analysis that 35 years are deficient, including the years 1981, 1998 and 1999 are considered dry (the deficit between 40 and 60\% of the annual average) and 32 years are affected by moderate drought (deficit varies between 20 and 40\% of the annual average) (Meddi $\mathrm{H}$ et al, 2007). The index focuses reduced rainfall has allowed us to observe the variability and periods of deficits and surpluses (Figure 3) (A Musy et al, 2004).The analysis of this index reveals that the period of most severe deficit is spread over the period 1976-2004 with the exception of a few years. A surplus period that spans the period (1943-1975), with some years of losses was also highlighted. A maximum deficit ($172 \mathrm{~mm}$ ) was recorded during the year 1981 with a rainfall index equal to -1.62 . The year 1964 has a maximum excess with $166 \mathrm{~mm}$ rainfall with an index around 1.8.

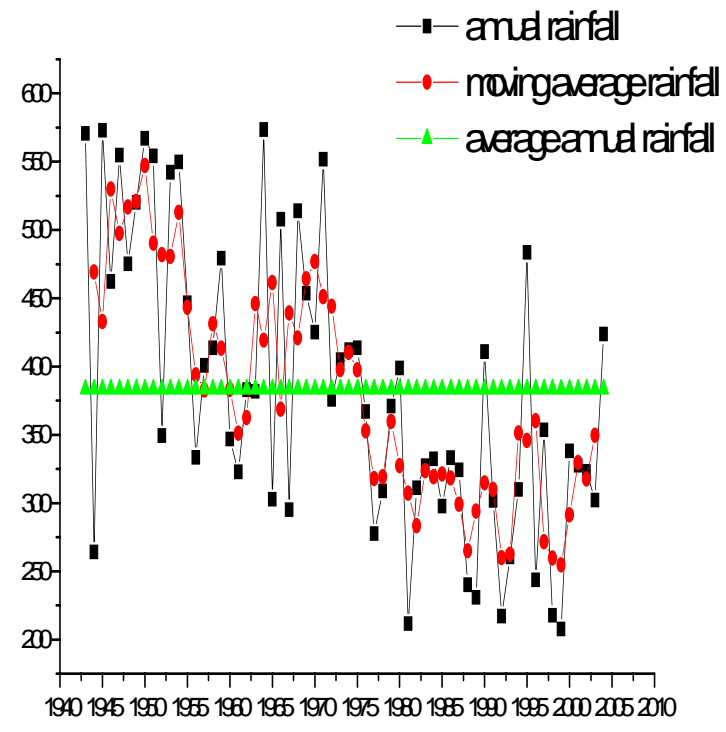

Fig 2: Average rainfall interannual and moving average in the sub-watershed of the river Fekan (1943-2004) 


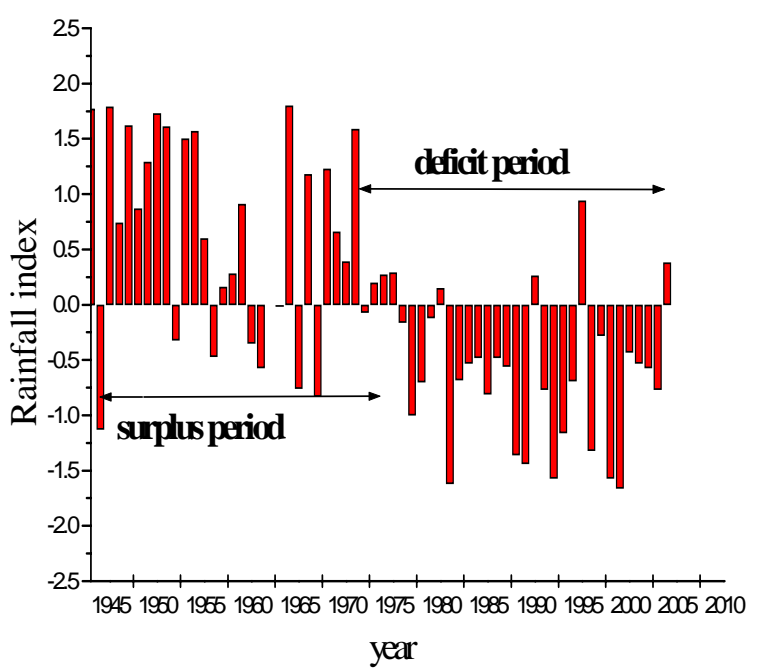

Fig 3: inter-annual variations of rainfall indices in the sub-watershed of the river Fekan (1943-2004)

The 2.2-inputs and water deficit: The figure 4, illustrates the deficit and surplus (P-ETR) * at the annual station Mascara for the period 1977-2006 (the availability of climate data). It is noted that the deficit era began in 1996 and extends until the year 2006 except for 1995. The maximum deficit is observed at 2002 with $49.4 \mathrm{~mm}$. For manifests itself against the excesses from the year 1979 with a maximum of $40 \mathrm{~mm}$. It is thus clear that the deficit represents about $60 \%$ of the water balance. The contributions of rainfall calculated for the period 1977-2006 across the sub-watershed is estimated at $453.6 * 10^{6} \mathrm{~m}^{3} /$ year. The calculation of flow and infiltration is through the method of Thornthwaite. The surface and subsurface flow occurs in the months of November, December, January and February, with a total water space of about $77 \mathrm{~mm}$, with a maximum of $23.8 \mathrm{~mm}$ in the month of December.

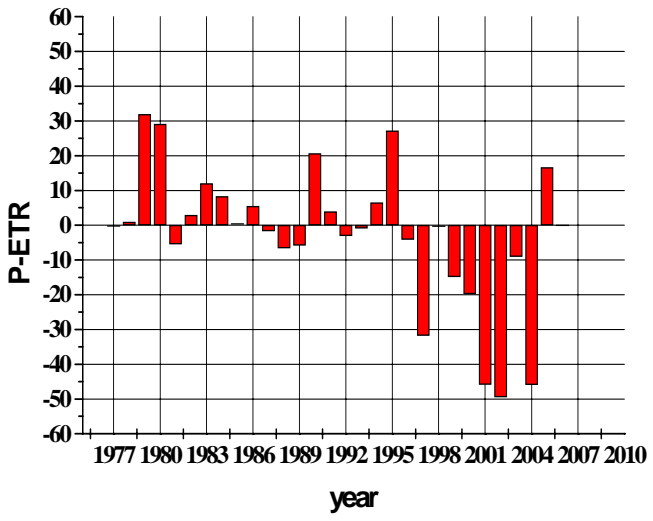

Fig 4: Annual surplus and deficit $(\mathrm{mm})$ calculated by the method of Turc (1977-2006)

Surface Water Resources: The figure 5 shows that the decrease in river flow Fekan is more noticeable since 1980-1981 until the end of the observation period except for the years 1994-1995 and 20032004. This decrease follows the same pattern as that for rainfall over the same period. The recent fluctuations show that the surface water resources in a remarkable decrease during this period.

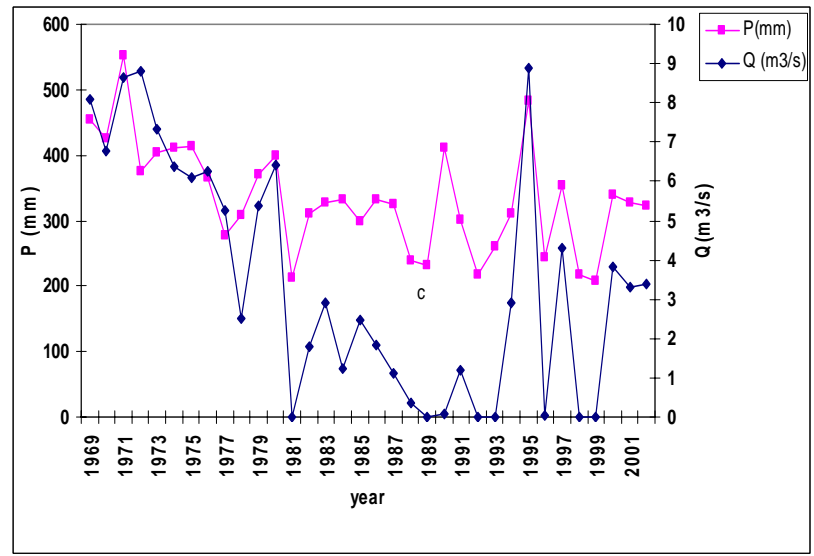

Fig 5: Average rainfall and flow past (1969-2004)

As the analysis focused reduces the index (Figure 6) flow and rainfall for the period 1969-2004, clearly shows two distinct periods. A surplus period that occurs between 1969 and 1980 with the exception of 1977 and another deficit between 1981 and 2004. The effect of deficit and excess rainfall is well illustrated on the hydrological regime.

${ }^{*} \mathrm{P}$ : average rainfall interannual

* ETR: actual evapotranspiration 
Groundwater Resources: Plain Ghriss is an independent hydrogeological unit, formed by a superposition of layer permeable aquifers separated by impermeable formations that hold and put in charge of these layers (P Sourisseau, 1973). Thus, four different aquifers have been identified (Figure 7). To observe the fluctuation of groundwater of the plain, light wells and a piezometer network were selected (Table
In the control wells No. 381/212 (Figure 8), the static water level was 2.75m in March 1970 just before going down in October 1986 to $13.13 \mathrm{~m}$, a lowering of $10.38 \mathrm{~m}$. In September 1997 he reached $45.25 \mathrm{~m}$, a lowering of $42.50 \mathrm{~m}$ during the period 1970-1997. In the control wells No. 1014/213, the static water level measured in 1952 was $3.80 \mathrm{~m}$. The reduction observed at this point during the period 1952 September 1997 is $32.41 \mathrm{~m}$ (Figure 8).

Table 2: Network monitoring groundwater (piezometers) and control wells

\begin{tabular}{|c|c|c|c|c|c|c|}
\hline \multirow[t]{2}{*}{$\mathrm{N}^{\circ}$} & \multirow[t]{2}{*}{ Designation } & \multirow[t]{2}{*}{ Abbreviation } & \multirow[t]{2}{*}{ Monitored groundwater } & \multicolumn{2}{|c|}{ Lambert Cordinates } & \multirow[t]{2}{*}{ Depth (m) } \\
\hline & & & & $X(\mathrm{~km})$ & $\mathrm{Y}(\mathrm{km})$ & \\
\hline 01 & Piezometer (Tizi) & P1-1 & Alluvium & 263,42 & 230,25 & 50,00 \\
\hline 02 & Piezometer (Tizi) & $\mathrm{P} 1-2$ & Lacustrine limestone & 263,40 & 230,25 & 190,00 \\
\hline 03 & Piezometer (ONM) & P0-3 & Lacustrine limestone & 271,20 & 232,75 & 95,00 \\
\hline 04 & Piezometer (Matmore) & $\mathrm{PO}-4$ & Dolomitic limestone & 274,90 & 227,35 & 131,00 \\
\hline 05 & Piezometer (S/ Kadda) & P0-5 & Sandstones and sands & 280,27 & 228,25 & 80,00 \\
\hline 06 & Piezometer (Tighennif) & P0-6 & Sandstones and sands & 284,10 & 237,65 & 90,00 \\
\hline 07 & $\begin{array}{c}\text { Piezometer (way Tigennif- } \\
\text { S/kadda) }\end{array}$ & P0-7 & Pebbles and gravel & 284,77 & 233,60 & 60,00 \\
\hline \multicolumn{7}{|c|}{ Control wells } \\
\hline \multirow[t]{2}{*}{$\mathrm{N}^{\circ}$} & \multirow[t]{2}{*}{ Abbreviation } & \multirow{2}{*}{\multicolumn{2}{|c|}{ Location }} & \multicolumn{3}{|c|}{ Lambert cordinates } \\
\hline & & & & \multicolumn{2}{|c|}{$\mathrm{X}(\mathrm{km})$} & $\mathrm{Y}(\mathrm{km})$ \\
\hline 01 & $381 / 212$ & \multicolumn{2}{|c|}{ Northern Froha } & \multicolumn{2}{|c|}{266.03} & 230.70 \\
\hline 02 & $281 / 243$ & \multicolumn{2}{|c|}{ South East Ghriss } & \multicolumn{2}{|c|}{270.65} & 217.97 \\
\hline 03 & $1014 / 213$ & \multicolumn{2}{|c|}{ South East Tighennif } & \multicolumn{2}{|c|}{286.60} & 235.50 \\
\hline
\end{tabular}

Source (ONM): National Meteorological Office

In March 1970, the static water level in observation well No. 281/243, was 31.24m in October 1986 down to 52.00. In September 1997, before drying, the water level reached $64.57 \mathrm{~m}$.

The decrease recorded in March 1970 in March 1997 is $38.76 \mathrm{~m}$ (Figure 8).

Similarly, observations made on static levels, show that all layers are affected by the strong cuts (Figure 9). Even the water of dolomitic limestone which was considered at one time as a groundwater reserve, given the depth of its roof, is affected.

To evaluate the fluctuation of groundwater, it was based on the Relative Variation of the Static level (VNS) of the web (Dasylva Sylvester et al 2005).The static water level is steadily declining with the exception of piezometers P0-5 and P0-6 which have some de $1.15 \mathrm{~m}$ charging for 2000 and $0.55 \mathrm{~m}$ in 2004 . The largest variation of the static level is noticed in piezometers $\mathrm{P} 1-2$ and $\mathrm{P} 0-4$ with $9.63 \mathrm{~m}$ and $10.25 \mathrm{~m}$ respectively for the years 1999 and 2002. It seems that the years 2000 and 2004 excess rainfall, with $130.5 \mathrm{~mm}$ and $121.6 \mathrm{~mm}$ respectively, did not participate in food webs, with the exception of P0-5 and P0-6. The causes do not appear due only to lack of rainfall, but also to the intense use of this resource by agriculture (irrigation), water supply, population growth (Figure 10). 


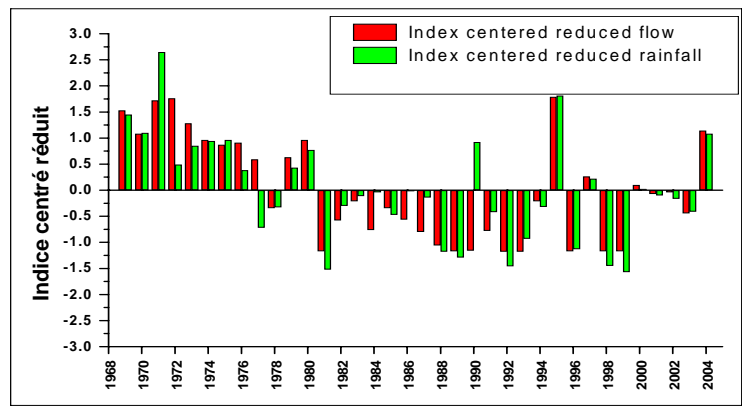

Fig 6: The index of the centered reduced rainfall and runoff (1969-2004)

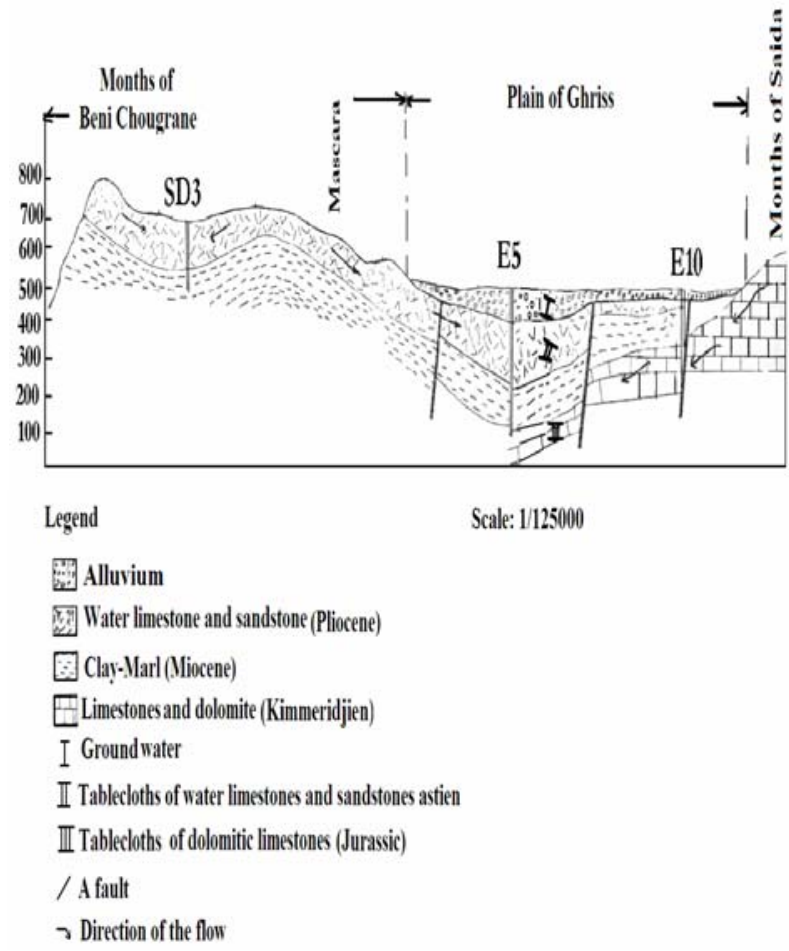

Fig 7: Hydrogeological section (NW-SE) (P Sourisseau, 1973)

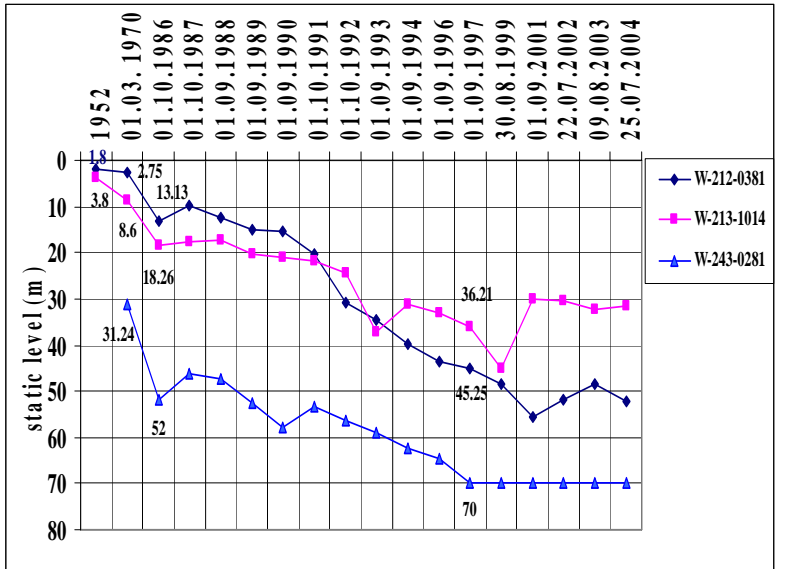

Fig 8: The variation in static control wells

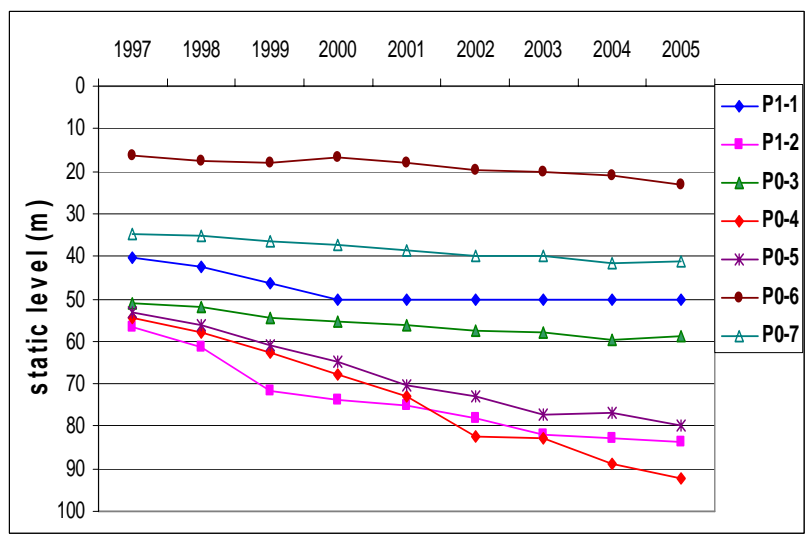

Fig 9: The variation of static levels of monitoring wells

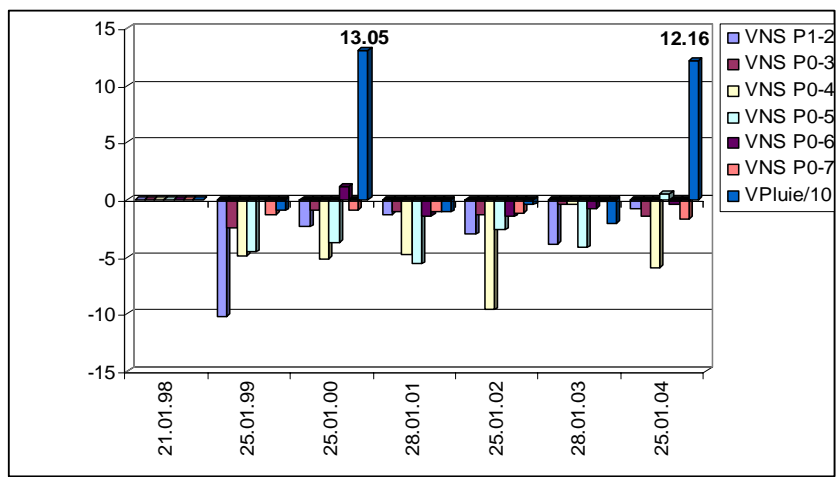

Fig 10: relative variation of static groundwater levels and the annual rainfall 


\section{CONCLUSION}

In the study area agriculture consumes a large part of water resources. In fact, the irrigation and drinking water supply of cities are ensured by pumping in a large number of works capturing all the plies.

It was clear from this study that over $57 \%$ of years are considered dry years and $52 \%$ are affected by moderate drought. The annual deficit and surplus at the station for the period 1977-2006 Mascara shows that the deficit era began in 1996 and extends until the year 2006 except for 1995. As surface runoff and groundwater occurs in the months of November, December, January and February, with a total water space of about $77 \mathrm{~mm}$.

The observations on static levels, show that all layers are affected by the strong cuts. These cuts do not only due to lack of rainfall, but also to the intense use of this resource by agriculture, water supply, population growth.

\section{REFERENCES}

Azaz H (2001). Impact of climate on surface water resources and groundwater in watersheds of the upper and middle Tafna (west Algeria). Memory of Magister , p122.

Meddi $\mathrm{H}$, Meddi M (2007):: Spatial and temporal variability of rainfall in North-west Algeria, Geographia Technica, No. .2: p50-50

Musy A, higy C (2004). Course of general hydrology, French University Polytechnic presses, 326p.

Sourisseau P (1973)._Synthesis on the hydrogeology of the plain Ghriss (Mascara). Center Studies Diagnosis of the Works and Structure 1-84pp.

Sylvestre Dasylva et Claude Cosandey (2005). The operation of the Quaternary Sands Tablecloth Food compromised by the lack of rainfall recharge. Geocarrefour Number vol. 80 / 4 (2005) Water scarcity: a natural or social issue? 